\title{
IMPACT OF TOMATO PLANT PROTEINASE INHIBITORS ON THE DIGESTIVE PHYSIOLOGY OF THE COTTON LEAFWORM, SPODOPTERA LITTORALIS (BOISD.)
}

\author{
AMIN, LOBNA R., A. M. ABD EL GHANY and T. R. AMIN \\ Plant Protection Research Institute, ARC, Dokki, Giza, Egypt \\ (Manuscript received 8 June 2015)
}

\begin{abstract}
$\mathrm{P}$ lant proteinase inhibitors were (PIs) extracted from tomato leaves (Solanum lycopersicum L.) to test their effect on the digestive physiology of Spodoptera littoralis in relation to growth and development of the larvae. Larvae fed on leaves treated by crude extract protein of PIs $\left(10 \mathrm{mg}\right.$ protein $\left.\mathrm{m}^{-1}\right)$. The continuous feeding of the cotton leafworm on treated leaves from egg hatching led to significant inhibition of the $4^{\text {th }}$ larval instar gut proteases (decreased by $32.9 \%$ as compared to control). Effects of PIs on protein digestion suggested that PIs might alter protein metabolism. The results showed that total proteins were significantly reduced in treated larvae as compared to control $(P<$ 0.05 ), but free amino acids were more affected than proteins ( $P<$ 0.01 ). Also, enzymes related to protein metabolism were also changed due to feeding on leaves treated by PIs. On the other hand, the study revealed that continuous feeding on tomato PIs reduced S. littoralis larval and papal weight, and caused $6.7 \%$ abnormalities i.e. appearance of larval-pupal intermediates. It could be suggested that tomato PIs act by in vivo inhibiting of the cotton leafworm gut proteases, not by resulting in hyperproduction of proteolytic enzymes related to protein metabolism such as Glutamic oxaloacetic transaminase (GOT) to compensate the reduced amount of available proteins due to treatment. It is the first time to test PIs activity towards the native pests. Results presented here demonstrating that the use of tomato PIs might be of a significant value in the field of pest control.
\end{abstract}

Key words: Plant proteinase inhibitors, proteases, growth, development, Spodoptera littoralis.

\section{INTRODUCTION}

Biopesticides are certain types of pesticides derived from natural materials as animals and bacteria (Muraleedharan and Elayidam, 2008). One of the natural materials derived from plants are plant proteinase inhibitors which are considered among the defensive chemicals in plant tissues that contribute to their resistance toward insects populations (Ahn and Zhu-Salzman, 2009). Defensive role of proteinase inhibitors (PIs) against insects was demonstrated by classical study on tomato and potato plants by Green and Ryan (1972). During the last three decades, effects of PIs on many different types of animals, including insects, were previously 
reported (Broadway and Duffey, 1986; Damle et al., 2005; de Oliveira et al., 2014). Generally, PIs act as antimetabolic proteins, which interfere with the digestive process of insects by inhibition of proteases in insects gut, causing a reduction in the availability of amino acids necessary for their growth and development (Lawerence and Koundal, 2001).

The cotton leafworm, Spodoptera littoralis (Biosed.) is a serious lepidopteran pest. The difficulty in controlling this kind of pest promotes the development of alternatives for pest control, among them, the use of proteins with insecticide effect. In view of limited information available on the use of PIs against the cotton leafworm, the goal of the present work was to determine effect of feeding on PIs treated leaves on the digestive physiology of $S$. littoralis larvae in relation to their growth and development. Tomato leaves (Solanum lycopersicum L.) were chosen as a source of PIs.

\section{MATERIALS AND METHODS}

\section{- Insects:}

S. littoralis larvae were obtained from a laboratory strain maintained in Plant Protection Research Institute, Sharkia branch, Egypt. The strain was introduced to the laboratory as egg masses and used in the present study.

\section{- PIs extraction:}

Protease inhibitors were extracted from tomato plant leaves, $S$. lycopersicum L. planted at Qaha (Qaliubia governorate). Plants were grown for 7 weeks (vegetative stage) in an air conditioned greenhouse at approximately $27^{\circ} \mathrm{C}$. Leaves from 80 plants were harvested and dried in an oven at $40^{\circ} \mathrm{C}$. Crude extracts proteins including PIs were precipitated with ammonium sulphate (70\%), resuspended in water $\left(10 \mathrm{mg}\right.$ protein $\left.\mathrm{ml}^{-1}\right)$, dialyzed and used as a source of PIs for larvae treatment.

\section{- Treatment:}

To detect in vivo effects of tomato PIs crude extract protein, the newly hatched first larval instar was treated from egg hatching till sixth larval instar stage by the extract (14 days). Clean castor bean leaves were dipped in the extract for 60 seconds, then they were hanged up to dry at room temperature for approximately 1 hr. Newly hatched larvae (200 larvae/jar) were confined with treated leaves in glass jars covered with muslin. Control larvae were provided with leaves dipped in water. Treated leaves were replaced by new ones every $24 \mathrm{hr}$ and introduced to larvae for 
feeding. Larval weight and mortality (if present) were recorded daily throughout the experimental time, besides other biological parameters were also recorded.

\section{- Preparation of insects for analysis:}

The whole fourth larval instar insects were prepared as described by Amin (1998) to show the effect of continuous feeding by tomato PIs extract on in vivo proteins and amino acids contents, and transaminases activity. Larvae were homogenized in distilled water $(50 \mathrm{mg} / \mathrm{ml})$. homogenates were centrifuged at 8000 r.p.m. for $15 \mathrm{~min}$ at $4^{\circ} \mathrm{C}$ in a refrigerated centrifuge. The deposits were discarded and the supernatant was kept in a deep freezer $\left(-20^{\circ} \mathrm{C}\right)$ till use for the assays.

Crude gut extracts used for protease assays were prepared by removing the digestive tracts from $S$. littoralis fourth larval instar as described by Osuna-Amarillas et al. (2012). Guts were homogenized in assay buffer (0.IM phosphate buffer, pH 8) and centrifuged at $14,000 \mathrm{~g}$ for $10 \mathrm{~min}$ at $4{ }^{\circ} \mathrm{C}$, the supernatants were collected, and used as enzyme source.

\section{- Biochemical experiments:}

Total proteins were determined by the method of Bradford (1976), using Coomasie Brilliant blue G250, and bovine serum albumin as standard. Amino acids were colorimetrically assayed by ninhydrin reagent according to the method described by Lee and Takabashi (1966).

Glutamic pyruvic transaminase (GPT) and glutamic oxaloacetic transaminase (GOT) were determined according to the method of Reitman and Frankle (1957). Total proteolytic activity in gut extracts was measured as described by Tatchell et al. (1972) by measuring the increase in free amino acids split from substrate protein (bovine serum albumin). The produced amino acids were assayed as described above.

\section{-Statistical analysis:}

All obtained values were pooled from triplicate, using Costat statistical software (Cohort Software, Brekely), means and standard deviations were obtained, and the data were analyzed by completely randomized ANOVA. The means were separated using Duncan's multiple range tests.

\section{RESULTS AND DISCUSSION}

\section{- Effect on gut proteases:}

The continuous feeding of the cotton leafworm larvae on PIs treated leaves from egg hatching led to inhibition of $4^{\text {th }}$ larval instar gut proteases (Table, 1 ). The results revealed that gut proteases were significantly decreased by $32.9 \%(P<0.05)$ 
than control. Gut proteases activity was 134 and $90 \mathrm{n}$ mole D, L-alanine/min/mg protein for control and treated larvae, respectively.

Table 1. In vivo effect of tomato PIs extract on gut proteases of S. littoralis $4^{\text {th }}$ larval instar after continuous feeding on the inhibitor from egg hatching.

\begin{tabular}{|l|c|c|c|}
\hline & Control & Treated & \% decrease \\
\hline $\begin{array}{l}\text { Proteases (n mole D, L- } \\
\text { alanine/min/mg protein) }\end{array}$ & $134 \pm 9.24^{\mathrm{a}}$ & $90 \pm 4.62^{\mathrm{b}}$ & 32.9 \\
\hline
\end{tabular}

- Date presented as the means \pm S.E.

- Means are significantly different $(P<0.05$, ANOVA $)$.

\section{- Effect on protein metabolism:}

The effect of PIs on protein digestion might alter protein metabolism. Table (2) shows the effects of the tomato inhibitor on protein metabolism of the fourth larval instar after continuous feeding on PIs treated leaves from egg hatching. Total proteins were significantly reduced in treated larvae $(P<0.05)$. Proteins were 14.83 and $19.3 \mathrm{mg} / \mathrm{g}$. b.wt for treated and control larvae, respectively.

Free amino acids were more affected than proteins $(P<0.01)$. They were 20.56 and 30.5 ug D,L-alanine/g.b.wt for treated and control larvae, respectively (Table, 2). On the other hand, enzymes related to protein metabolism were also changed due to feeding on leaves treated by PIs. Treatment enhanced GOT activity, while it decreased the titre of GPT $(P<0.01)$. The activity of GOT was 511 and 453

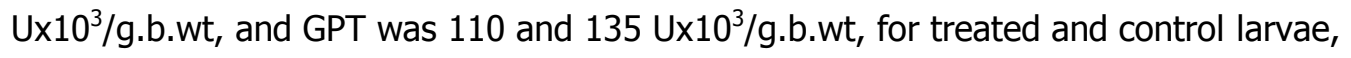
respectively.

Table 2. Effect of tomato PIs extract on protein metabolism of S. littoralis 4th larval instar after continuous feeding on the inhibitor from egg hatching.

\begin{tabular}{|l|c|c|c|c|}
\hline \multicolumn{1}{|c|}{ Insects } & $\begin{array}{c}\text { Total protein } \\
\text { (mg/g.b.wt) }\end{array}$ & $\begin{array}{c}\text { Free amino acids (ug } \\
\text { D, L-alanine/ } \\
\text { g.b.wt) }\end{array}$ & $\begin{array}{c}\text { GOT } \\
\left(\text { Ux } 10^{3} / g . b . w t\right)\end{array}$ & $\begin{array}{c}\text { GPT } \\
(\text { Ux10 } / g . b . w t)\end{array}$ \\
\hline Control & $19.00 \pm 0.95^{\mathrm{a}}$ & $30.5 \pm 1.06^{\mathrm{a}}$ & $453 \pm 6.65^{\mathrm{b}}$ & $135 \pm 3.29^{\mathrm{a}}$ \\
\hline Treated & $14.83 \pm 0.76^{\mathrm{b}}$ & $20.6 \pm 0.79^{\mathrm{b}}$ & $511 \pm 5.66^{\mathrm{a}}$ & $110 \pm 3.58^{\mathrm{b}}$ \\
\hline
\end{tabular}

- Date presented as the means \pm S.E.

- Means, within a columun, bearing different subscripts are significantly different $(P<0.01$, ANOVA), except total proteins $(P<0.05)$. 


\section{- Effect on growth and development:}

Feeding on PIs significantly $(P<0.05)$ reduced growth of the cotton leafworm, S. littoralis different larval instars (Fig. 1). The results revealed that the average larval weight was 10, 23, 35, 76.6, 116 and $211 \mathrm{mg} /$ larva for the instars from the first to the last instar (six instars), of treated larvae, respectively. The control larvae had average larval weight of $18,25,45,91.3,154$ and $279 \mathrm{mg} / \mathrm{larva}$ for the same instars, respectively.

The significant effect on growth expanded to show the effect of tomato PIs extract on the biological activity of $S$. littoralis.

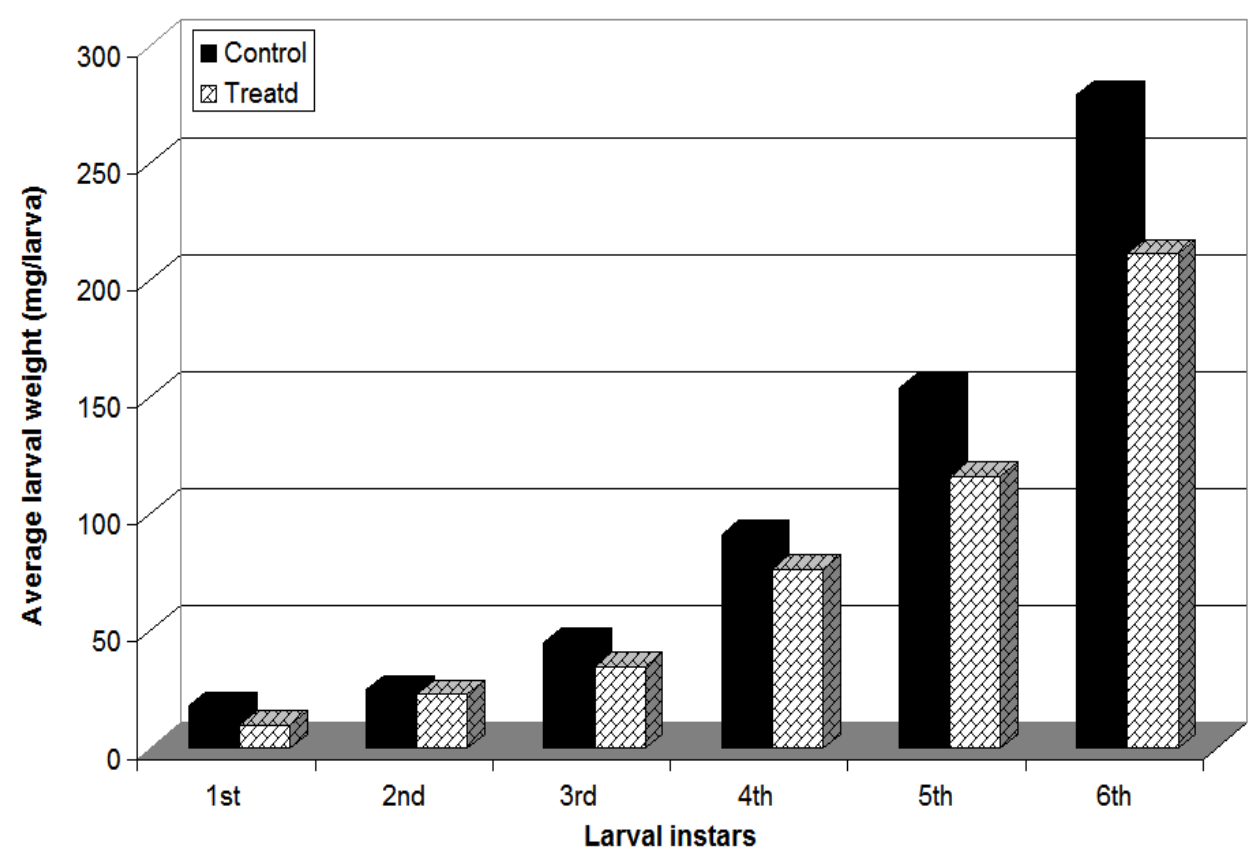

Fig. 1. Average larval weight of Spodoptera littoralis larval instars fed with tomato PIs.

Table (3) illustrates that PIs did not cause any mortality $(=0 \%)$ in treated larvae. Also, PIs did not affect the duration of the larval period. Larval period of control larvae was 14 days, while it was 15 days in larvae fed PIs extract. However, treatment led to appearance of larval-pupal intermediate in $6.7 \%$ of insects. The pupal weight was significantly reduced in treated larvae $(P<0.05)$. the average pupal weight was $111 \mathrm{mg} / \mathrm{pupa}$, while it was $140 \mathrm{mg} / \mathrm{pupa}$ in control.

Several studies illustrate that PIs inhibit in vivio proteases (e.g. Broadway, 1995). Tomato PIs, in the present work, were significantly $(P<0.05)$ decreased protease activity by $32.9 \%$ less than control. This reduction could led to reduction of total body proteins and free amino acids, which emphasized by the study. 
Table 3. Biological activity of tomato PIs extract on Spodoptera littoralis fed treated leaves during the larval stage.

\begin{tabular}{|l|c|c|}
\hline \multicolumn{1}{|c|}{ Parameter } & Control & Treated \\
\hline Larval period in days & $14 \pm 0.46^{\mathrm{a}}$ & $15 \pm 0.28^{\mathrm{a}}$ \\
\hline Larval mortality\% & 0.00 & 0.00 \\
\hline Larval-pupal intermediate \% & 0.00 & 6.70 \\
\hline Pupal weight $(\mathrm{mg})$ & $140 \pm 10.4^{\mathrm{a}}$ & $\begin{array}{c}111 \pm 2.89^{\mathrm{b}} \\
(\mathrm{P}<0.05)\end{array}$ \\
\hline
\end{tabular}

- Data are presented as the mean \pm S.E.

- Means bearing different subscripts, within row, are significantly different.

In vivo study revealed that continuous feeding on tomato PIs treated leaves reduced S. littoralis larval and pupal weight, and caused abnormalities i.e. appearance of larval-pupal intermediates. Previous and current literatures confirm the present results. Broadway and Duffey (1986) found that potato proteinase inhibitor II and soybean trypsin inhibitor significantly reduced growth and development of larval Heliothesis zea and S. exiqua. PIs from different plant sources had biological activity. Bitter gourd PIs caused deformities in the developing larvae of $\mathrm{H}$. armigera and $\mathrm{S}$. litura, and has adverse effects on pupae and adults (Telang et al., 2003). Reviewing tomato plant, Damle et al. (2005) found that tomato (Lycopersicon esculentum Mill) PIs had negative effects on various developmental parameters of $\mathrm{H}$. armigera, most significantly on fecundity.

In spite of tomato PIs affected larval biology, no mortality was recorded in the present study. The concentration of the inhibitor used (10 ug protein $\mathrm{ul}^{-1}$ ) might be responsible for such results. de Oliveira et al. (2014) emphasized that concentration of the inhibitor is critical, below it might mortality did not occur.

There are many reports to explain mechanism by which PIs affect biological activity of insect pests, Lepidopteran insects have serine proteinases as a major component of their digestive complement and among them, trypsin-and/or chemotrypsin-like are the most commonly found proteinases (Purcell et al., 1992). PIs enter in the insect digestive tract a long with food and block the protein digestion, hence starving the insect for amino acids and energy, resulting in retardation of growth and development (Ryan, 1990). In addition, PIs may hinder the transport of enzymes and their hydrolysis products, which in combination with reduced proteolysis 
may limit the availability of amino acids for larval growth leading to poor development and high mortality (Macedo et al., 2004).

It could be suggested that tomato PIs by in vivo inhibiting proteases, not by resulting in hyperproduction of proteolytic enzymes due to chronic ingestion of PIs as reported by Broadway and Duffey (1986). Instead, PIs result in activation of some enzymes related to protein metabolism such as GOT to compensate the reduced amount of available proteins due to treatment.

It is the first time to test PIs activity towards the native pests in Egypt. PIs extract from tomato ( $S$. lycopersicum) leaves caused deleterious effects on the digestive proteinases, growth and development of $S$. littoralis larvae. Results presented here demonstrating that the use of tomato PIs might be of a significant value in the field of pest control. Also, it could be a useful strategy in development of modified plants with enhanced resistance to the cotton leafworm.

\section{REFERENCES}

1. Ahn, J. and K. Zhu-Salzman. 2009. Cm Cat D, a Cathepsin D-like protease has a potential role in insect defense against a phytocystatin. J. Insect Physiol., 55: 678-685.

2. Amin, T.R. 1998. Biochemical and physiological studies of some insect growth regulators on the cotton leafworm, Spodoptera littoralis (Biosd.). Ph D. Thesis, Fac. Sci., Cairo Univ.

3. Bradford, M.M. 1976. Rapid and sensitive method for quantitation of protein utilization principle of protein-dye binding. Analyt Biochem., 72: 248-254.

4. Broadway, R. and S.S. Duffey. 1986. Plant proteinase inhibitors : mechanism of action and effect on the growth and digestive physiology of larval Heliothis zea and Spodoptera exiqua. J. Insect Physiol., 32: 827-833.

5. Broadway, R.M. 1995. Are insects resistant to plant proteinase inhibitors. J. Insect Physiol., 14: 107-116.

6. Cleveland, T. E. and L.L. Black. 1985. Partial purification of proteinase inhibitors from wounded tomato plants. Plant Physiol., 69: 537-542.

7. Damle, M.S.; A.P. Giri; M.Sainani and V.S. Gupta. 2005. Higher accumulation of proteinase inhibitors in flowers than leaves and fruits as a possible basis for differential feeding preference of Helicoverpa armigera on tomato (Lycopersicon esculentum Mill, V. Dhanashree). Phytochem., 66: 2659-2667. 
8. de Oliveira, C.F.R.; S. Marangoni and M.L.R. Macedo. 2014. The trypsin inhibitor from Entada acaciifolia seeds affects negatively the development of Mediterranean flour mothy, Anagasta kuehneilla. Pestci. Biochem. Physiol., 108: 74-79.

9. Green, T. R. and C.A. Ryan. 1972. Wound-induced proteinase inhibitors in plant leaves: a possible defense mechanism against insects. Science, 175: 776-777.

10. Lawerence, P.K. and K.R. Koundal. 2002. Plant protease inhibitors in control of phytophagous insects. Electron. J. Biotechnol., 5: 93-109.

11. Lee, Y.P. and T. Takabshi. 1966. An improved colorimetric determination of amino acids with the use of ninhydrin. Analyti Biochem., 14: 71-77.

12. Macedo,M.R.L. ; C.M. De Sa ; M.D.G.M. Freire and J.R.P. Parrra. 2004. A kunitztype inhibitor of coleopteran proteases isolated from Adenantera pavonina L. seeds and its effect on Callosobruchus maculates . J.Agric.Food Chem., 52:25332540 .

13. Muraleedharan, D. and U.G. Elayidam. 2008. Prospects and promises of endocrine biopesticides. J. Biopestic., 30: 6-11.

14. Osuna-Amarillas, P.S.; F.J. Cinco-Moroyoqui; J.L. Cardenas-Lopez; J.M.EzquerraBrauer; R.Stelo-Mundo; M.O. Certez-Rocha; J.M. Barrom-Hoyos; O. RouzaudSandez and J. Borboa-Flores. 2012. Biochemical and kinetic characterization of the digestive trypsin-like activity of the lesser grain borer, Rhyzopertha dominica (F.) (Coleoptera : Bostrichidae). J. Stored Products Res., 51:41-48.

15. Purcell, J.P.; J.P. Greenplate and D. Douglas. 1992. Examination of midgut luminal proteinase activity in six economically important species. Insect Biochem. Mo. Biol., 22: 41-47.

16. Reitman, S. and S. Frankle. 1957. Colorimetric method for aspartate and alanine transaminases. Amer. J. Clin. Pathol., 28: 56.

17. Ryan, C.A. (1990): Proteinase inhibitors in plants : genes for improving defenses against insects and pathogens. Annual Rev. Phytopathol., 28: 425-449.

18. Tatchell, R.J.; S.F. Araman and F.N. Boctor. 1972. Biochemical and physiological studies of certain ticks (Ixodoidae). Z. Parasitenk, 39: 3454-350.

19. Telang,M.; A. Srimivasan ;A.Patankar ;A. Harsulkar; V.Joshi ; A. Damle; ;V. Deshpande ; M. Sainani; P.Ranjekar ; G.Gupta ; A.Birah ; S.Rani ; M.Kachole; A. Giri and V. Gupta. 2003. Bitter gourd proteinase inhibitors; potential growth inhibitors of Helicoverpa armigera and Spodoptera litura. Phytochem. , 63 :643652. 


\section{تأثير مثبطات إنزيم البروتينيز النباتية علي فسيولوجيا الهضم في دودة ورق القطن}

$$
\text { لبني رئيس أمين أحمد مليجي عبد الغني طارق رئيس أمين }
$$

قسم بحوث فسيولوجيا الآفات، معهذ بحوث وقاية النباتات، مركز البحوث الزراعية، الدقي، الجيزة

Solanum lycopersicum L. تم استخــاص مثنطات أنزيم البروتينيز من أوراق الطماطم

وذلك لدر اسة تأثير ها علي فسيولوجيا الهضم في دودة ورق القطن وعلاقة ذلك بنمو وتطور الآفة.

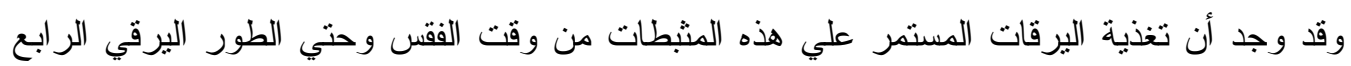

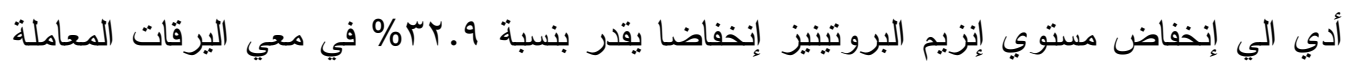

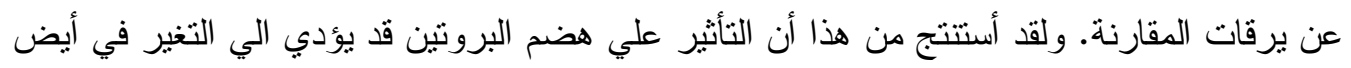
البروتين و هذا ما أنثتته هذه الدراسة. فقد تبين أن مستوي البروتين و الأحماض الأمينية الحرة و وأيضا

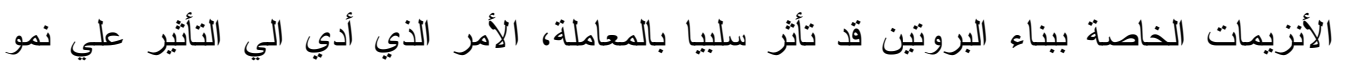

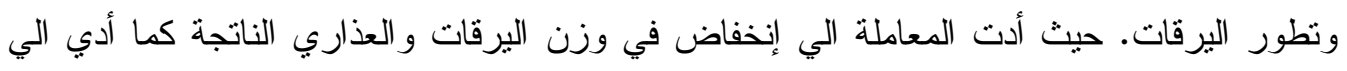

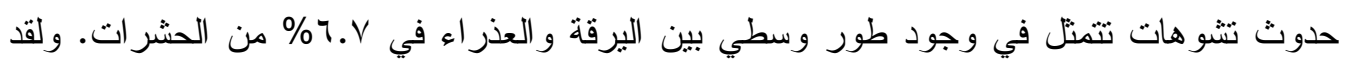

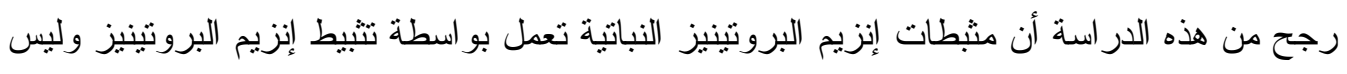

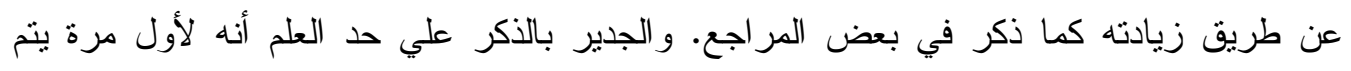

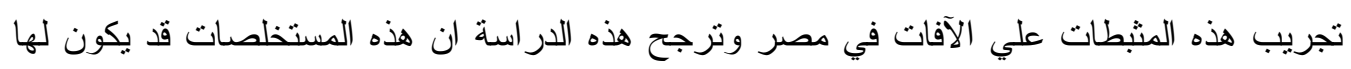
أهمية كبيرة في مجال مكافحة الآفات. 